STATE OF ILLINOIS

DEPARTMENT OF REGISTRATION AND EDUCATION

DIVISION OF THE

NATURAL HISTORY SURVEY

STEPHEN A. FORBES, Chief

Vol. XIII. BULLETIN Article XIV.

\title{
FOREST INSECTS IN ILLINOIS
}

I. THE SUBFAMILY OCHTHIPHILINAE

(Diptera, Family Agromyzidae)

BY

J. R. MALLOCH

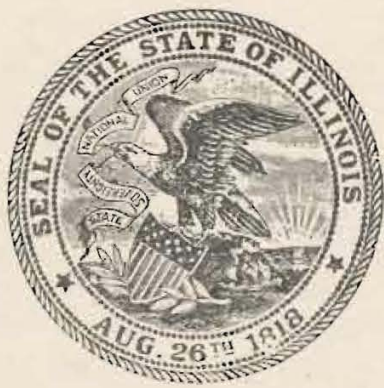

PRINTED BY AUTHORITY OF THE STATE OF ILLINOIS

URBANA，ILLINOIS

January, 1921 


\section{ERRATA}

Page 97, line 17, for first larval read pupal.

Page 112, in legend, for jonessi read jonesii.

Page 114, in legend', for or read of.

Page 125, line 4, for Bonosa read Bonasa.

Page 131, in legend, for hirundinaceus read hirudinaceus.

Page 138, last line, for coccoon read cocoon.

Plate XII, explanation page, next to last line, for acrivora read aerivora.

Plate XIII, explanation page, next to last line, for White-grubs read White-grub.

Page 293, Figure $5 a$ was reversed in printing, and the two items of the legend should change places.

Page 515, second table, for Pelocoris femorata read Pelocoris femoratus. 
Article XIV.-Forest Insects in Illinois. I. The Subfamily Ochthiphilinae (Diptera, Family Agromyzidae). By J. R. Malloch.

This paper deals with a small group of two-winged flies, or Diptera, belonging to the subfamily Ochthiphilinae, family Agromyzidae, and is intended to serve as an index both to the habits and the systematic relations of the species.

\section{Characters of Subfamily}

Costa complete, extending to apex of fourth vein; fifth vein not flexed proximad of outer cross-vein; anal vein incomplete; both basal cells present, sometimes the cross-vein at base of discal cell very weak; vibrissae absent; postvertical bristles absent or present, when present convergent; tibiae without preapical bristle; interfrontal bristles absent; orbits never with an anteriorly directed bristle; arista bare or pubescent; sternopleura with one or more bristles; propleural bristle absent; clypeus small.

\section{Distribution and Biology of Genera}

This subfamily contains only seven genera. Of these, four are known to occur in Illinois; the other three each contain only one North American species and are more southern in their known distribution. With the exception of the genus Cryptochaetum the genera have not been considered as of economic importance and but little has been published on the biology of the other genera, this paper containing the most complete series of records of the larval habits extant. The predaceous habits of the larvae, which so far as known feed upon aphids and scale insects, give to the species an economic status which does not belong to any other subfamily in the acalyptrate Diptera, the only true aphidophagous larvae in the Cyclorrhapha occurring in the Syrphidae. All species of the genus Leucopis feed on aphids and scale insects, and it is possibly due to their small size that their importance as destroyers of these insects has not been more than casually mentioned in literature.

I present keys to the genera of the subfamily, including the larvae known to me, and keys to all the North American species of the genera Pseudodinia and Leucopis sens. lat.

The larvae of Leucopis are subject to attack by chalcid parasites, the imago of the parasite emerging through a ragged hole which it gnaws in the anterior portion of the dorsum of the puparium of the host. 


\section{Keys to Genera}

\section{LARVAE AND PUPARIA}

1. Anal respiratory processes thread-like, one of them at least ten times as long as body, coiled inside of body of host; both larva and puparium internal in host (Icerya purchasi)............. Cryptochaetum Rondani

- Anal respiratory processes very short and stout, sometimes sessile, not thread-like, and not as long as body; larva and puparium not internal

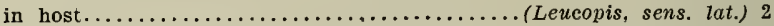

2. Body almost cylindrical, not tapered posteriorly, with minute warty or setulose armature; anal respiratory processes sessile, situated much above level of venter and widely separated: Host, Pulvinaria vitis L.........

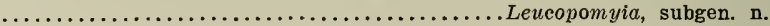

- Body distinctly flattened ventrally, tapered both anteriorly and posteriorly, usually with minute warty or setulose armature; anal respiratory processes stalked, usually lying close against the surface to which the larva or puparium is adhering............. Leucopis Meigen, sens. str.

IMAGINES

1. Orbits with one or more pairs of distinet bristles $\ldots \ldots \ldots \ldots \ldots \ldots \ldots \ldots 2$

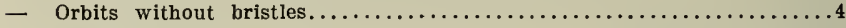

2. Head pointed at base of antennae, the face almost horizontal; wings dis- tinctly spotted............................. Scrometopia Schiner

- Head not pointed at base of antennae, face short and nearly or quite vertical (Pl. XLVI, Fig. 5, 6, 9, 10) ; wings unspotted................

3. Thoracic dorsum with four pairs of bristles (Pl. XLVI, Fig. 2) ; mesopleura bare; ocellar bristles absent.................. Chamaemyia Panzer

- Thoracic dorsum with three pairs of bristles (Pl. XLVI, Fig. 1); mesopleura bare; ocellar bristles present.................. Ochthiphila Fallen

- Thoracic dorsum with two pairs of bristles (Pl. XLVI, Fig. 3); mesopleura with one strong bristle; ocellar bristles present but weak...........

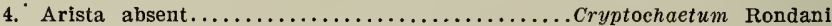

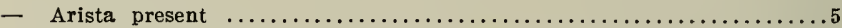

5. Costa with small setulae on under surface; species glossy blue-black......

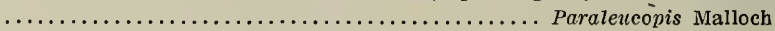

- Costa not setulose; species densely gray pruinescent.... Leucopis Meigen

\section{Acrometopia Schiner}

The only described North American species of this genus, punctata Coquillett, has been recorded only from Georgia.

Larval habits unknown. 


\section{Chamaemyia Panzer}

This genus has usually been considered as a synonym of Ochthiphila but it is readily separated by means of the characters cited in the above key to genera.

The only species, elegans Panzer, occurs in Europe and has been recorded from New Jersey. There are two specimens in our collection from Illinois: Champaign, July 25, 1889, and Mayview, July 31, 1891 (Terrill).

Larval habits unknown.

\section{Ochтнiphila Fallen}

There is but one species of this genus in our collection from Illinois, polystigma Meigen. It is generally distributed throughout the state, and is apparently as common in this country as in Europe.

I know nothing of the larval habits.

\section{Pseudodinia Coquillett}

\section{KET to SPECIES}

1. Frons anterior to ocelli, distinctly longer than wide (PI. XLVI, Fig. 7, 11); tibiae and tarsi yellow......................... potita Malloch

- Frons anterior to ocelli at least as wide as long; apices of tibiae and the

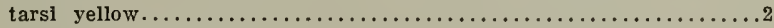

2. Frons anterior to ocelli much wider than long; apices of third and fourth veins divergent.......................... varipes Coquillett

- Frons anterior to ocelli as wide as long; apices of veins 3 and 4 not di-

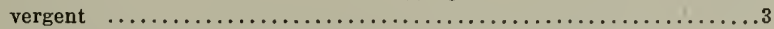

3. Thorax and abdomen polished, almost without pruinescence; last section of fourth vein more than twice as long as preceding section...........

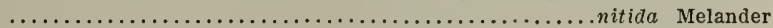

- Thorax and abdomen shining, with distinct pruinescence; last section of fourth vein twice as long as preceding section.......pruinosa Melander

\section{Pseudodinia nitida Melander}

Three specimens with data as follows, from Illinois: Urbana, August 30, 1914, and September 3, 1916; and White Heath, July 11, 1915. Taken by the writer.

Larval habits unknown.

\section{Pseudodinia Polita Malloch}

A common species in some parts of Illinois. Our specimens are from Centerville, August 16, 1914, 5 specimens; White Heath, May 30 , 
1915, 3 specimens; Muncie, June 3, 1917, and August 15, 1917, two specimens; Augerville, June 6, 1915, 1 specimen; Dubois, May 24 and 25, 1917, 4 specimens; and Carbondale May 15, 1910, 1 specimen. All except the last specimen taken by the writer.

Larval habits unknown.

\section{Cryptochaetum Rondani}

The only species of this genus in North America, iceryac Williston, does not occur in Illinois. The species was introduced into California from Australia to control the mealy citrus-bug in which the larvae are parasitic. In being an internal parasite the species differs from those of Leucopis, the larvae of the latter being predaceous.

\section{Paraleucopis Malloch}

This genus contains but one species, corvina Malloch, which does not occur in Illinois so far as we are aware.

Larval habits unknown.

\section{LEUCOPIS Meigen, sens. lat.}

There are at present in the list of North American Diptera seven species of the genus Leucopis. A key to six of these was published by Dr. A. L. Melander in 1913.* Subsequently Dr. J. M. Aldrich described the seventh speciest.

Dr. E. P. Felt recently submitted to me for identification several specimens which belong to an undescribed species which is represented also in the collection of the Natural History Survey, and herein I am presenting a key to all the North American species in the hope that by so doing I may make it possible for students to identify their specimens with more certainty than is possible by using the previously published keys.

I find that there are certain very important chaetotaxic differences between some of the species which warrant me in erecting two new subgenera for the reception of two species. It may be that other systematists will consider these segregates entitled to generic rank, but they very closely resemble the species of Leucopis in habitus and markings as well as in larval habits and structure, so that from my point of view the placing of the species in subgenera is more appropriate than either placing them in the same genus or erecting genera for them.

KeY to SUbGenera

1. Thorax with a pair of strong bristles between the posterior pair of dorso-

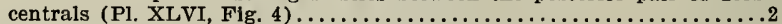

* Jour. N. Y: Ent. Soc., Vol. 21, p. 232.

† Jour. Econ. Ent., Voi. 7, p. 404. 1914. 
- Thorax without any bristles between the posterior pair of dorsocentrals; ocellar bristles absent....................... Leucopis Meigen

2. Ocellar bristles absent..................... Leucopomyia, subgen. n.

- Ocellar bristles present (Pl. XLVI, Fig. 8)........ Neoleucopis, subgen. n.

Leucopis Meigen, sens. str.

Key to SPECIES

1. Third antennal segment yellow; thorax and abdomen without black or brown stripes or spots, basal segment of the latter blackened except on posterior margin.................... flavicornis Aldrich

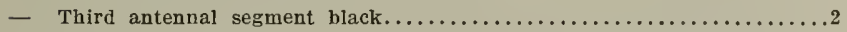

2. Basal two antennal segments yellow, contrasting conspicuously with the black third segment; mesonotum without distinct vittae, usually with 4 pairs of weak dorsocentrals; legs yellow, femora darkened in middle.. ...................................

- Basal two antennal segments not conspicuously paler than third; species

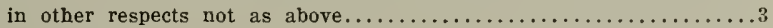

3. Frontal lunule transverse on its upper margin; thorax and abdomen dark gray, thorax not vittate, and with four series of acrostichal setulae between the dorsocentrals, abdomen with basal tergite almost entirely and the second largely fuscous, slightly shining; last section of fourth vein five or six times as long as preceding section; last section of fifth vein almost or quite twice as long as outer cross-vein; male bypopygium with a very long curved central process............. piniperda, sp. n.

- Frontal lunule.arcuate on upper margin, almost transverse in simplex; thorax with more than four series of acrostichal setulae between dorsocentrals; male hypopygium without a long curved central process....4

4. Abdomen with a small central spot and a larger one on each side of it on each of segments two to four inclusive black...................

- Abdomen with or without a small black central spot on segments two to four inclusive, but without the lateral spots except on second segment..6

5. Thorax with two brown vittae................. bellula Williston

- Thorax not vittate.......................maculata Thompson

6. Frontal orbits well differentiated from interfrontalia, each orbit wider than the latter, the entire frons pale gray, not vittate; genal bristle long; wing-veins 3 and 4 parallel apically, not convergent; tibiae and tarsi yellowish, the former slightly darkened in middle...orbitalis, sp. $\mathrm{n}$.

- Frontal orbits poorly defined, not at all differentiated from interfrontalia, and not as wide as the latter, the frons usually distinctly vittate......7 
7. Several minute setulae in front of genal bristle (Pl. XLVI, Fig. 12); penultimate section of fourth vein at least as long as, generally longer than, ultimate section of fifth (Pl. XIVII, Fig. 1); usually one and sometimes two long setulae in front of anterior dorsocentral bristle; fore tibiae and tarsi yellow.........................major, sp. n.

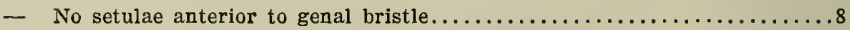

8. Fore tarsi largely or entirely yellow $\ldots \ldots \ldots \ldots \ldots \ldots \ldots \ldots \ldots \ldots$

- Fore tarsi largely or entirely black......................

9. Large species, $2 \mathrm{~mm}$. or over in length; thorax with two faint brown vittae; basal abdominal tergite black except along posterior margin, second with two small round black spots, third and and fourth each with a central black spot on anterior margin................ bella Loew

- Smaller species, less than $2 \mathrm{~mm}$. in length; thorax without distinct vittae; basal abdominal tergite bronzy fuscous except laterally, second with two large poorly defined bronzy fuscous submedian spots on anterior

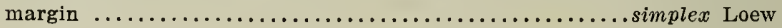

10. Entire fore metatarsus yellow; genal bristle very short; frontal lunule setulose; abdomen marked as in simplex; veins 3 and 4 parallel apically ........................................

- At most only the base of fore metatarsus yellow..................1

11. Small species, barely over $1 \mathrm{~mm}$. in length; thorax and abdomen lead-gray pruinescent; fore tarsi entirely, mid and hind pairs except base of metatarsi, black...................................

- Larger species, averaging $2 \mathrm{~mm}$. in length, thorax and abdomen whitish gray pruinescent; fore metatarsus yellow at extreme base, the other tarsi with at least the basal two segments yellowish...... americana, sp. $\mathrm{n}$.

\section{Descriptions and Records of Illinois Species \\ LEUCOPIS PEMPHIGAE, sp. $\mathrm{n}$.}

Male and Female.-Black, opaque, densely whitish gray pruinescent, Frons slightly rufous anteriorly, but only noticeably so when the surface has been wet, in well-preserved specimens densely whitish gray pruinescent; basal two antennal segments yellow, third deep black, slightly gray pruinescent; palpi black. Thorax not distinctly vittate, the areas occupied by the lateral vittae in other species a little darker gray than the remainder of disc. Abdomen slightly testaceous at apex; hypopygium testaceous; basal tergite with two large, rounded, poorly defined brownish fuscous spots, third and fourth sometimes with a small linear dark spot in center at base, second with two small round fuscous spots. Legs testaceous yellow, femora usually darkened on middle. Wings white, veins brownish except at bases. Calyptrae white. Halteres creamcolored. 
Frons almost parallel-sided, sparsely. hairy, over one third of the head-width at anterior margin; orbits narrower than interfrontalia; third antennal segment higher than long; genal bristle slender. Mesonotum with three or four dorsocentral bristles; about six series of setulae between the dorsocentrals, median setulae not forming stripes except near anterior margin. Hypopygium as in Plate XLVII, Figures $i, 11$, and 12. Veins 3 and 4 distinctly convergent at apices; penultimate section of fourth vein about one third as long as ultimate, and longer than last section of fifth vein.

Length, 2 mm1.

Type, male, allotype, and five paratypes. Carbondale, Ill., July 6, 1909, reared from larvae from Pemphigus gall. The species is evidently predaceous on the gall-maker.

Specimens emerged as adults July 15 and $27,1909$.

\section{LEUCOPIS PINIPERDA, sp. $\mathrm{n}$.}

Male and Fcmalc.-Black, opaque, densely gray pruinescent. Frons unicolorous pale gray pruinescent; antennae and palpi black, second segment of former pale gray pruinescent. Thorax not vittate. Abdomen slightly shining; basal tergite almost entirely brownish fuscous, second less broadly fuscous, the dark parts of tergites more distinctly shining than remainder of dorsum; hypopygial forceps testaceous. Legs black, bases of mid and hind tarsi and sometimes the knees in male testaceous, base of fore tarsus and apices of tibiae pale in female. Wings clear, veins fuscous. Calyptrae and halteres yellowish.

Frons a little over one third of the head-width, with sparse, short, erect hairs; orbits almost uniformly wide for their entire lengtl, each about half as wide as interfrontalia; ocelli in an almost equilateral triangle; lunule broadly transverse on its upper margin, nearly bare; third antennal segment higher than long; second segment of arista about four times as long as thick. Thorax with two or three pairs of dorsocentrals; dorsal setulae sparse, about four series between the dorsocentrals, some lying between the posterior pair. Hypopygium small with a very long curved central process, as in Plate XLVII, Figure 2. Ving-veins 3 and 4 almost parallel on their apical portions; last section of fourth vein five or six times as long as preceding section, the latter very much shorter than last section of fifth vein.

Length, $1-1.5 \mathrm{~mm}$.

Type, male, Urbana, Ill., April 29, 1916, in forestry of University of Illinois. Allotype, Urbana, Ill., July 5, 1915, on tree-trunk. Paratype, male, Boulder, Col., August 19, 1918, reared from needles of Pinus scapulorum (E. Bethel). .

The type and allotype were collected by the writer in the vicinity of pine trees. The larvae are very probably predaceous on aphids occurring on pine. 


\section{LEUCOPIS ORBITALIS, sp. $\mathrm{n}$.}

Female.-Black, opaque, densely pale gray pruinescent. Orbits darker than interfrontalia, the latter slightly testaceous; antennae black, second segment conspicuously whitish pruinescent; palpi black. Thorax not vittate. Basal abdominal tergite brownish fuscous except on posterior and lateral margins, second with a pair of large, poorly defined, round fuscous spots, the, dark parts slightly shining. Legs yellowish testaceous, coxae and femora largely fuscous, apices of tarsi infuscated. Wings clear, veins brown, pale basally. Calyptrae white. Halteres pale yellow.

Frons flattened, parallel-sided, a little over one third as wide as head, with sparse microscopic hairs; lunule rounded above; each orbit wider than interfrontalia, anteriorly; antennae as in pemphigae; palpi smaller than usual; genal bristle long, the area surrounding it nearly bare. Mesonotum with three or four pairs of dorsocentrals, the anterior two or three pairs weak; setulae between dorsocentrals sparse, three or four series, extending to level of posterior dorsocentrals, but irregularly; dorsal setulae not in stripes anteriorly. Third and fourth veins parallel on apical portions, penultimate section of fourth vein about one fourth as long as ultimate, and shorter than last section of fifth.

Length, $2 \mathrm{~mm}$.

Puparium.-Reddish testaceous, slightly shining.

Distinctly flattened on venter, tapered slightly at both ends, depressed at anterior extremity and slightly so at posterior, though convexly so; surface with minute setulose armature, most distinct on anal segments. Anterior respiratory processes minute, black, with about four branches; anal respiratory processes stout, closely adherent to surface of leaf, armed with microscopic setulae, separated by about twice the basal diameter of one process, each less than twice as long as thick.

Length, $2.5 \mathrm{~mm}$. ; diameter at middle, $.75 \mathrm{~mm}$.

Type and paratype, Dundee, June $\gamma, 1916$. Reared from pine twig infested by Kermes.

\section{LEUCOPIS MAJOR, sp. $n$.}

Male and Female.-Black, densely whitish gray pruinescent. Interfrontalia when seen from behind dark gray, the orbits almost white; antennae black, basal two segments paler, the second whitish pruinescent; palpi black. Dorsum of thorax with a brown vitta on each side along the lines of dorsocentrals, which extend to posterior margin; no other markings present. Abdomen with first tergite black except laterally, and narrowly so on posterior margin, second tergite with two large round submedian black spots, and a much less distinct dark streak between them which does not extend to posterior margin; third and fourth tergites 
with only the central streak. Legs yellowish testaceous, coxae, and femora except their apices fuscous, tibiae in middle and the apical tarsal segment sometimes slightly darkened. IVings clear, costal and first to fifth veins brown. Calyptrae white. Halteres yellow.

Eyes bare; frons distinctly narrowed posteriorly, at vertex less than one third of the head-width, both orbits and interfrontalia with numerous microscopic pale hairs: lunule large, exceeding in size the third antennal segment, regularly rounded above, its upper half hairy; third antennal higher than long; second segment of arista at least three times as long as thick; face concave, receding below; several short setulae anterior to the genal brjstle; palpi broad. Dorsum of thorax with rather dense short setulae, the median line almost obliterated; usually three and sometimes four dorsocentrals present, and between them $s$ or more series of short setulae which extend almost to posterior margin; scutellar bristles equal in length. Abdoninal tergites 1 to 4 in female subequal, fifth short; ovipositor as in Figure 6, Plate XLVII; hypopygium of male as in Figures 4, 8 , and 10 , Plate XLVII. Legs normal. Wings broad; veins 3 and 4 distinctly convergent apically; penultimate section of fourth vein usually longer than ultimate section of fifth.

Length, $2.5-3 \mathrm{~mm}$.

Type, female, allotype, and four female paratypes, St. Joseph, Ill., May 3, 1914 (J. R. Malloch).

Larval host unknown.

\section{LEUCOPIS SIMPLEX Loew}

I have before me a series of 6 specimens of this species which I took at Dubois, Ill., May 21-25, 191\%, and one from Muncie, Ill., May 24, 1914.

The characters cited in the key to species should serve to distinguish this species from its allies. Male hypopygium as in Plate XLVII, Figure 9.

The larval host is unknown to me.

\section{LEUCOPIS PARALLELA, sp. $\mathrm{n}$.}

Female.-Black, densely gray pruinescent, the color of the pruinescence of abdomen paler than that of thorax. Frons lead-gray, orbits paler; antennae black, second segment whitish pruinescent; palpi black. Thorax lead-gray pruinescent, not vittate. Abdomen whitish gray pruinescent, first tergite subshining fuscous except on lateral margins, second tergite with the usual fuscous spots very large, fused centrally and extending to anterior margin, the other tergites unmarked. Legs black, extreme apices of femora, bases and apices of tibiae, entire fore metatarsus, and the mid and hind tarsi except the apical segment yellow. IVings clear, veins brown. Calyptrae white. Halteres white.

Frons at vertex less than one third of the head-width, slightly widened anteriorly, the surface with microscopic hairs; lunule hairy, subtrans- 
verse above, not as large as third antennal segment, the latter as long as high; face concave in center; genal bristle very short; palpi slightly broadened. Thoracic dorsum rather densely and evenly setulose on disc, with two pairs of dorsocentrals; basal pair of scutellar bristles shorter than apical pair. Fifth abdominal tergite about as long as fourth. Legs normal. Wings narrow; veins 3 and 4 parallel apically, penultimate section of fourth vein slightly longer than ultimate section of fifth, the latter longer than outer cross-vein.

Length, $1 \mathrm{~mm}$.

Type, Muncie, Ill., July 5, 1914 (J. R. Malloch).

This species very closely resembles simplex Loew, but differs in color of legs, in having the third and fourth veins parallel, the fifth abdominal tergite longer, and the genal bristle shorter. Both species have the discal thoracic setulae continued to posterior margin between the dorsocentrals

Larval host unknown.

\section{LEUCOPIS MINOR, sp. $\mathrm{n}$.}

Male.-Differs from the preceding species in having the spots on second tergite small and widely separated, the posterior margin of first tergite gray pruinescent, the legs black, with bases of all tibiae and of mid and hind tarsi yellowish.

Genal bristle larger than in parallela. Discal thoracic setulae discontinued proximad of posterior dorsocentral; basal scutellar pair of bristles slightly smaller than apical pair. Veins 3 and 4 subparallel apically; penultimate section of fourth vein distinctly shorter than-ultimate section of fifth, the latter much longer than outer cross-vein.

Length, $1 \mathrm{~mm}$.

Type, Dubois, Ill., August 9, 1917 (J. R. Malloch).

A female in poor condition but which appears to belong to this species was taken at Champaign, Ill., July 24, 1889 (Marten and Terrill).

Larval host unknown.

\section{LEUCOPIS AMERICANA, sp. n.}

Male and Female-Black, densely grayish white pruinescent, the abdomen in some specimens almost silvery. Frons with the interfrontalia darker than the orbits, appearing vittate; second antennal segment conspicuously whitish pruinescent. Thorax with or without two brown vittae. Abdomen normally as in major, the central spots sometimes obsolete. Legs with a larger amount of yellow than in minor, the base of fore metatarsus nearly always yellowish.

Third anfennal segment higher than long. Discal setulae as in minor. Fifth tergite in female very short. Legs normal. Veins 3 and 4 generally slightly but noticeably convergent apically; position of outer cross-vein variable; wing broader than in minor.

Length, $2-2.5 \mathrm{~mm}$. 
Type, male, allotype, and two female paratypes, Urbana, Ill., June, 191\%. Reared from larvae found feeding on aphids on Spirea vanhouteii (J. R. Malloch). This series has the thorax vittate.

The puparia of this. species, from which the type series emerged, differ from those of orbitalis in having the surface except on venter covered with wart-like protuberances which are tipped with minute spines or setulae. These protuberances are not serially arranged and are separated by a little wider space than the width of the base of one protuberance. The empty puparium is yellowish in color, slightly shining, with a pale brownish vitta between median line and dorsolateral margin. In form it is more robust than that of orbitalis and has a slight but evident longitudinal depression along each side, so that the portions dorsad and ventrad of the depression form rounded elevations. Anterior respiratory organs minute, with a few microscopic apical filaments; posterior respiratory organs pedunculate, about three times as long as their basal diameter, separated by a distance equal to their length, their surfaces warty, apical filaments very minute, apparently 4 or 5 in number.

Length, $3 \mathrm{~mm}$.; greatest width, $1 \mathrm{~mm}$.

This species is by far the commonest of the genus in the state, occurring in all the localities in which I have collected. It has previously been referred to in literature as nigricomis Egger, but I consider it inadvisable to use the name of a European species for one taken in this country until a very careful comparison of the American and European specimens has been made.

I have before me a very large number of specimens which I consider belong to this species. Those with larval data are as follows: 2 specimens, reared from larvae found feeding on aphids on black locust, Chicago, Ill., September 1S, 1908 (J. J. Davis); 1 specimen, reared from a larva found feeding on aphids on Spirea vanhouteii, Urbana, Ill., June 25, 1916 (J. R. Malloch) ; 2 specimens, one with and one without vittae on thorax, reared from larvae found feeding on aphids on apple, America, Pulaski Co., Ill., June 30,1916 ; 4 specimens, reared from larvae found feeding on Aplis rumicis on thistle, Chicago, Ill, August 30, 1908 (J. J. Davis).

The other specimens in our collection bear no data as to larval foodhabits but are from the following localities: Urbana, Champaign, St. Joseph, Muncie, Monticello, Ashley, Meredosia, Algonquir, ard Waukegan.

\section{LEUCOPOMYiA, subgen. $n$.}

This subgenus differs from Leucopis in the larval stage in having the body cylindrical and evenly rounded at the posterior end, the anal respiratory processes sessile, situated high above the ventral level and widely separated, and the surface of the body with but indistinct spinose armature. The adult differs in having praescutellar acrostichal and no ocellar bristles.

Genotype, Leucoponyia pulvinariae, sp. $\mathrm{n}$. 


\section{LeUCOPOMYia PUlViNARIAE, sp. $\mathrm{n}$.}

Male and Female.-Black, opaque, densely pale gray pruinescent. Antennae black, basal two segments brownish, grayish pruinescent, third segment slightly brownish on inner side at base; palpi yellow; frontal triangle, orbits, and lunule whitish gray; ocelli reddish. Mesonotum with two broad brown sublateral vittae which do not extend to posterior margin, the submedian vittae pale gray and indistinct. Abdomen with basal tergite except its posterior margin black, second with a pair of black spots at base in center, third and fourth each with a rather indistinct black median spot at base in center. Legs yellowish testaceous, the femora except apices dark gray. Wings whitish, veins, except sixth, pale brown except at bases. Calyptrae white. Halteres cream-colored.

Frons above antennae one third of the head-width, narrowed posteriorly, at vertex about two thirds as wide as at anterior margin; ocelli in an equilateral triangle; each orbit one third as wide as interfrontalia, densely hairy; ocellar triangle extending to anterior margin of frons, usually densely hairy; lunule large, rounded above, the surface with some minute hairs; third antennal segment not as long as wide; second segment of arista about four times as long as thick; face slightly receding; genal bristle strong. Thoracic dorsum rather densely setulose, at middle with about eight series of setulae between the vittae, the median setulae not-forming two distinct stripes except near anterior margin; a very strong pair of praescutellars present; sometimes there are three pairs of dorsocentrals present, the anterior pair weak. Abdominal tergites subequal. Legs stout, without bristles except at apex of mid tibia on ventral surface; the fore femur of male with a rather dense fringe of minute setulae on anteroventral surface. Third and fourth veins with apices slightly convergent, penultimate section of latter nearly half as long as ultimate; outer cross-vein about three fourths as long as last section of fifth vein.

Length, $2.5 \mathrm{~mm}$.

Puparium.-Reddish brown, opaque.

Almost cylindrical, very indistinctly flattened on ventral surface, tapered on thoracic segments, where it is depressed on dorsum. Surface with very minute setulose armature which is most noticeable, but only under a very high-power lens, at posterior extremity on dorsum. Anterior spiracles very small. Posterior spiracles sessile, distinguishable only under a strong magnification, situated well above the rounded caudal extremity, forming with the small anal orifice an almost equilateral triangle.

Length, $3 \mathrm{~mm}$; diameter, $1 \mathrm{~mm}$.

Type, male, allotype, and 10 paratypes, Shushan, N. Y., July 6, 1916, No. a30\%6, New York State College. Paratypes: female, Chicago, Ill., spring, 190\%; male, Algonquin, Ill., July 4, 1892. Both the New York specimens and the one from (hicago were reared from larvae found feeding on the cottony maple-scale (Pulvinaria vitis Linné). 
I have figured the hypopygium of the male last mentioned, which appears to present in the shape of the dorsal plate, with the truncate notch at its apex, quite a different form from other species of the group (Pl. XLVII, Fig. 3, 5).

Neoleucopis, subgen. n.

Differs from Leucopis in having a moderately strong pair of praescutellar acrostichals, and a pair of reclinate ocellar bristles.

Genotype, Neoleucopis pinicola, sp. n.

\section{Neoleucopis Pinicola, sp. n.}

Male and Fcmale.-Black, densely gray pruinescent, thorax subopaque, dorsum of abdomen shining on fuscous portions. Head black, frons densely pale gray pruinescent; antennae and palpi black; second segment of former whitish pruinescent. Thorax not vittate. Abdomen with dorsum of basal and second tergites fuscous. Legs black, knees (narrowly) and bases of mid and hind tarsi in male and of all tarsi in female yellowish. IVings hyaline, veins fuscous. Calyptrae and halteres whitish.

Frons a little over one third of the head-width, with very short pale hairs ; each orbit about one third the width of interf rontalia ; ocelli forming an equilateral triangle; ocellar bristles moderately long; lunule rounded above; third antennal segment not as long as high; genal bristle not surrounded with hairs. Thorax with two or three pairs of weak dorsocentrals, the anterior pairs weakest; about four series of setulae between the dorsocentrals; basal scutellar bristles much shorter than apical pair. Third and fourth wing-veins very slightly convergent apically; penultimate section of fourth vein from one sixth to one fourth as long as ultimate and much shorter than last section of $\mathrm{fifth}$.

Length, $1.25-1.75 \mathrm{~mm}$.

Type and one male paratype, Stratford, Ill., June 22, 1917 (J. R. Malloch). Allotype, Urbana, Ill., May 23, 1885. Paratype, one male, Urbana, Ill., July 31,1916 (J. R. Malloch).

The author's specimens were all taken on pine trees and the allotype, taken by some collector whose name is not on record, was beaten from pine also. Habits of larva unknown; probably predaceous on aphids on pine. 


\section{Thoracic and Cephalic Chaetotaxy of Ochthiphilinae}

FIG. 1. Ochthiphila polystigma, thorax, dorsal view.

Fig. 2. Chamaemyia elegans, same.

Fig. 3. Pseudodinia polita, same.

Fio. 4. Leucopomyia pulvinariae, same.

Fro. 5. Ochthiphila polystigma, head, dorsal view.

Fio. 6. Chamaemyia elegans, same.
Fro. 7. Pseudodinia polita, head, dorsal view.

FIG. 8. Neoleucopis pinicola, same.

Fı. 9. Ochthiphilia polystigma, head, lateral view.

Fro. 10. Chamaemyia elegans, same.

Fis. 11. Pseudodinia polita, same.

Fig. 12. Leucopis major, same. 


\section{Plate XlVI}

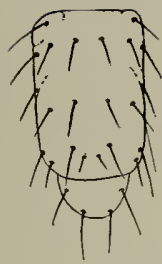

1
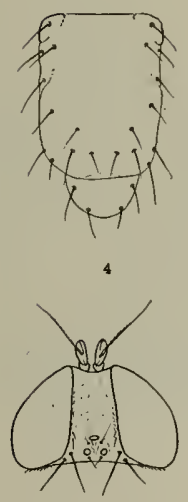

7

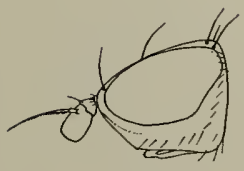

10

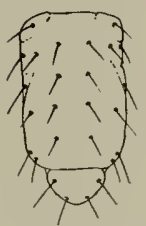

2

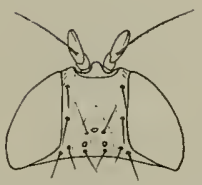

5

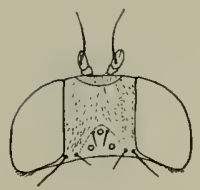

8

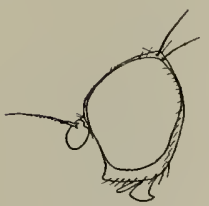

11

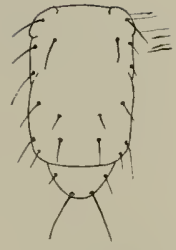

3

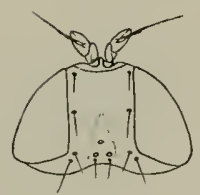

6

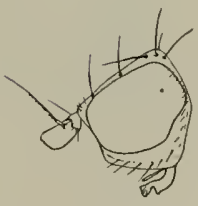

9

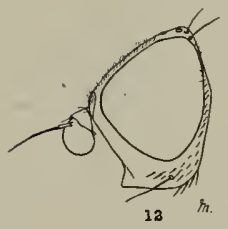




\section{Plate XLVII}

Wing Venation and Male and Female Genitalia of Ochthiphilinae

Frg. 1. Leucopis major, wing.

Fro. 2. L. piniperda, male hypopygium, lateral view.

Fro. 3. Leucopomyia pulvinariae, same.

Fre. 4. Leucopis major, same.

Fıo. 5. Leucopomyia pulvinariae, male hypopygium, caudal view.

Fre. 6. Leucopis major, female genitalia, lateral view.
Fro. 7. Leucopis pemphigae, hypopygium of male, lateral view.

Fro. 8. Leucopis major, same, caudal view.

FIG. 9. $L$, simplex, same, ventral view, one side.

Fio. 10. $L$. major, same.

Fro. 11. L. pemphigae, same, dorsocaudal view, one side.

Fra. 12. $L$. pemphigae, same, ventral view. 
361

Plate XLVII
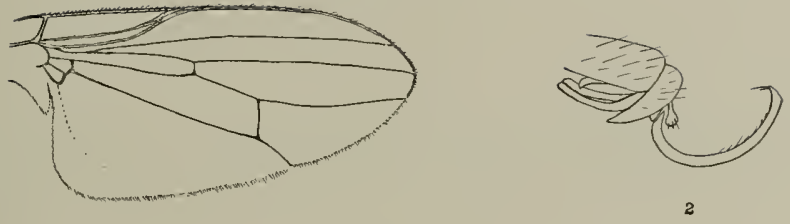

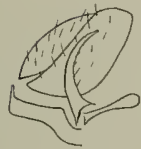

3
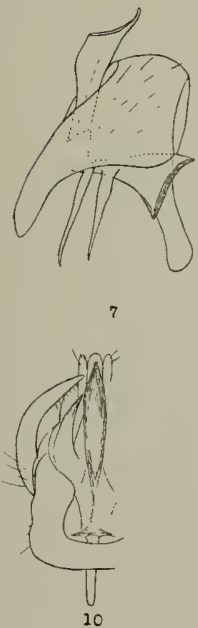
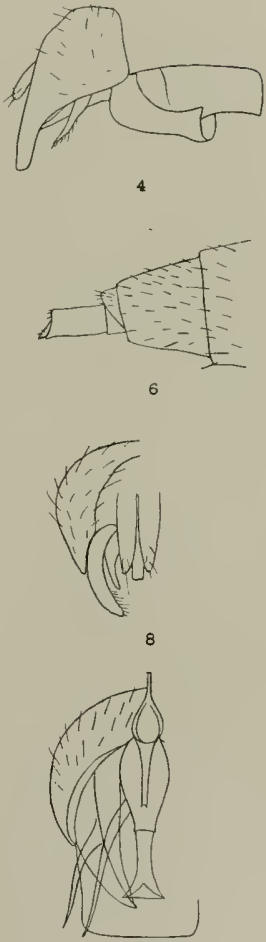

11
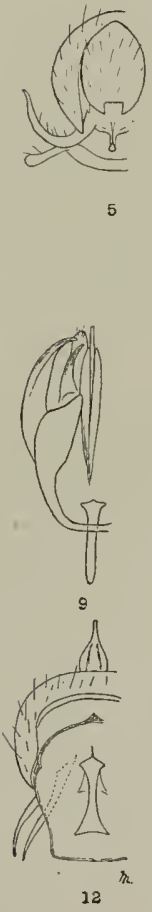